JONASZ PAWLACZYK

ORCID 0000-0002-7763-0196

STANISŁAW DYLAK

ORCID 0000-0002-8671-7349

Uniwersytet im. Adama Mickiewicza

$w$ Poznaniu

\title{
MŁODZIEŻ I JEJ OBECNOŚĆ W PRZESTRZENI CYFROWEJ W KONTEKŚCIE BUDOWANIA TOŻSAMOŚCI
}

\begin{abstract}
Aвstract. Pawlaczyk Jonasz, Dylak Stanisław, Młodzież i jej obecność w przestrzeni cyfrowej w kontekście budowania tożsamości [Youth and its Presence in the Digital World in the Context of Identity Development]. Studia Edukacyjne nr 57, 2020, Poznań 2020, pp. 145-160. Adam Mickiewicz University Press. ISSN 1233-6688. DOI: 10.14746/se.2020.57.10
\end{abstract}

The text focuses on presenting the issues related to the process of young people's building and developing identities and on underlining the impact of a broadly understood technology on this process. The very concept of identity, subject to many approaches and theories, is also discussed. The text draws attention to the school and the teacher as elements whose task should be to help students to cope with the challenges that today's (postmodern) world presents to young people. The goal is to enable the best conditions for self-development and building a stable and mature identity in an ever-changing environment. Technology is not seen only as a threat to man and his identity. However, the lack of a solid theoretical basis, regarding the impact of technology on identity building and preparation of appropriate preventive behavior, increases the risk of a negative impact of technology. The authors of the text strongly believe that changing the paradigm of human behavior can bring about beneficial effects on humanity, on the environment and on the entire planet.

Key words: identity, digital world, innovation at school, information

\section{Wstęp}

Krystyna Doktorowicz w książce Tożsamość w wieku informacji. Media. Internet. Kino zauważa: 
Media masowe, sieci informacyjno-komunikacyjne, Internet generują nowe zjawiska kulturowe i społeczne, których antycypacja jest niemal niemożliwa, a skutki rozpoznane zmuszają do nowego podejścia do procesów tożsamości we wszystkich aspektach $^{1}$.

Właśnie ta myśl może zostać uznana za punkt wyjścia niniejszego artykułu. Świat przez ostatnie 20/30 lat przyniósł nam wiele nowości, głównie z obszaru szeroko rozumianej technologii. Spotęgowało to, co od paru dekad jest obserwowane i przypisywane jako charakterystyczne dla czasów postmodernistycznych lub inaczej - ponowoczesności. Wraz z jej nadejściem minęły czasy, kiedy absolutne prawdy dotyczące świata były dostępne tylko wybranym ludziom (uczonym, księżom i nauczycielom) i to ci nieliczni posiadali niezachwianą pozycję jako edukator i mędrzec. Jak pisze Bauman w swojej książce:

Dla większości pedagogicznych obiektów ksiądz i nauczyciel byli jedynymi „oknami na świat", przekaźnikami informacji ponadśrodowiskowej i maklerami szerszej niż środowiskowa kultury. Każdy program edukacyjny mógł więc mieć własnego adresata i każdy mógł wobec swego adresata przyjmować pozę monopolistyczną².

Po czym dodaje:

Środki masowego przekazu były dla lokalnie i kategorialnie zorientowanych środowisk wychowawczych tym, co trąby Jozuego dla murów Jerycha. Mury oddzielające pedagogiczne enklawy legły w gruzach, a wraz z nimi znikła możliwość kierowania procesem uczenia się, planowania doboru wpływów wychowawczych, sterowanego programu nauczania. Krótko mówiąc, przepadła możliwość skutecznej kontroli nad środowiskiem wychowawczym, która tkwiła w tle każdej z dotychczasowych teorii i strategii pedagogicznych ${ }^{3}$.

We współczesnym świecie dostęp do informacji jest znacznie bardziej powszechny. W nauczycielu nie powinno szukać się jedynie źródła wiedzy, a raczej przewodnika, który pomoże uczniowi dostępne informacje przefiltrować, a własną wiedzę ustrukturyzować. Nauczyciel powinien być tym, który wie, jak się uczyć i pomagać uczniom właśnie w tym aspekcie. Wszelkie informacje są już dla ucznia dostępne w Internecie, jednak musi posiąść umiejętność korzystania z nich. W tym miejscu rola nauczyciela wydaje się niezastąpiona.

Obecny świat mocno wiąże się z technologiami, a te są ważnym i wciąż nowym elementem świata. Bez nich nie można właściwie mówić o ucze-

${ }^{1}$ K. Doktorowicz (red.), Tożsamość w wieku informacji. Media. Internet. Kino, Katowice 2015, s. 21-22.

2 Z. Bauman, Ponowoczesność jako źródło cierpień, Warszawa 2013, s. 251.

${ }^{3}$ Tamże. 
niu się i nauczaniu. Cechą charakterystyczną tych technologii jest ich powszechność. Niemal każde dziecko i dorosły mają z nimi w jakimś stopniu do czynienia $\mathrm{w}$ codziennym życiu, a ich znaczenie ciągle rośnie. Jedynie parę, paręnaście lat wystarczyło, by wiele wynalazków stało się integralną częścią życia większości ludzi: smartfony, laptopy, komunikatory/portale społecznościowe - by wymienić tylko kilka. W świat dorosłych wchodzą powoli roczniki dzieci, które urodziły się w świecie, gdzie technologia jest dla nich elementem absolutnie naturalnym, zastanym. Są oni nazywani cyfrowymi tubylcami. Chociaż samo określenie ma już dwadzieścia parę lat ${ }^{4}$, to jeszcze bardzo wielu rzeczy nie wiemy na temat wpływu technologii na ich funkcjonowanie i postrzeganie otaczającego świata. Dotychczas mieliśmy możliwość badania przez parę dekad jedynie ludzi, dla których technologia pochodziła z zewnątrz, była czymś nowym, obcym. Są to ludzie, których można nazwać, pozostając w konwencji cyfrowych tubylców, cyfrowymi imigrantami. Ma to znaczenie, biorąc w szczególności pod uwagę skłonności ludzi do odrzucania nowości, usztywniania swojej postawy względem niezrozumiałych rzeczy i naturalnym, bo powiązanym ze strefą komfortu, konserwatyzmem. Czynniki te powodują, iż zasadne staje się przypuszczenie, że wyniki badań cyfrowych imigrantów będą się różnić od wyników tych samych eksperymentów wykonanych na cyfrowych tubylcach. Nie jest natomiast nadal jasne i jednoznaczne, czy zmiany te będą korzystne, negatywne, czy - w perspektywie długofalowej - neutralne. Rozpowszechnienie technologii utworzyło możliwość zdobywania i wytwarzania informacji na nieznaną dotychczas skalę. W Encyklopedii pedagogiki XXI wieku ${ }^{5}$ można znaleźć hasło informacyjny zalew, które odnosi się do problemu zarówno bardzo dużej ilości informacji, jak i problemu z jej weryfikowalnością. Jest to definiowane w następujący sposób:

informacyjny zalew, zwany także informacyjnym lub cyfrowym potopem - to nadmiar informacji docierający do człowieka rozmaitymi kanałami informacyjnymi; powoduje, że informacje ważne i prawdziwe giną w natłoku mniej lub zupełnie nieistotnych, a w wielu wypadkach nieprawdziwych ${ }^{6}(. .$.$) tworzy to niekorzystne warunki, które nie$ tylko powodują informacyjny smog, na który składają się informacyjna mgła (informacje są w wielu różnych miejscach, nieuporządkowane, w dużym rozproszeniu) i informacyjny dym (informacje niekompetentne, błędne, specjalnie fałszowane), ale i mają bezpośredni wpływ na nas. Związane to jest ze zjawiskiem stresu informacyjnego (szczególna forma

${ }^{4}$ Pojęcie digital natives rozpropagował Marc Prensky, jednak po raz pierwszy zostało ono użyte przez innego badacza/artystę - Johna Perry Barlowa w Deklaracji niepodległości cyberprzestrzeni, w 1996 roku.

${ }^{5}$ Encyklopedia pedagogiczna XXI wieku, tom II, red. T. Pilch, Warszawa 2003.

${ }^{6}$ Tamże, s. 310. 
stresu poznawczego ${ }^{7}$ ), a powiązane jest $\mathrm{z}$ naszym biologicznym niedostosowaniem do tak szybkich zmian, jakie mają miejsce $\mathrm{w}$ dziedzinie cyfryzacji ${ }^{8}$.

\section{Budowanie Tożsamości}

Zmiany, o których mowa, mają duży wpływ na to, jak człowiek, w szczególności nastolatek, postrzega samego siebie. Nie ulega wątpliwości, że trudniej budować stabilną tożsamość $\mathrm{w}$ świecie podlegającym na wielu poziomach różnym zmianom. Szczególnie, kiedy dana osoba wystawiona na świat cyfrowy jest całkowicie nieprzygotowana, by w nim poprawnie funkcjonować i czerpać z niego korzyści. Zasadne jest zatem pytanie, czy człowiek jest w stanie przygotować się na funkcjonowanie w świecie cyfrowym? W analizach dotyczących technologii oraz ich wpływowi, punkt ciężkości znajduje się często na nieprawidłowościach i/lub zagrożeniach, a pomija się fakt, że odpowiednie korzystanie z nowinek technologicznych może przynieść pozytywny efekt dla ich użytkowników. W podobnym duchu wypowiada się wspomniana już Krystyna Doktorowicz, która twierdzi, że Internet jest miejscem, w którym dojrzała jednostka może w dużej mierze się samorealizować i spełniać:

Przyjmowanie różnych tożsamości w sieci przez dojrzałych użytkowników Internetu zaspokaja ich poczucie wolności, które w świecie realnym jest poważnie ograniczone przez systemy wartości, obyczajowości, religię czy normy kulturowe ${ }^{9}$.

Jednakże, w Internecie nie funkcjonują wyłącznie osoby o stabilnej, dojrzałej tożsamości, posiadającej trwałe jądro (hard core). Równie znacząco, a może przede wszystkim, Internet stanowi element, który uczestniczy w budowaniu wielu tożsamości poprzez przekazywanie różnych wzorców kulturowych, zachowań, mody i tym podobnych. Tak postrzegany jest on wyzwaniem, z którym musi zmierzyć się praktycznie każdy.

Mówiąc o tożsamości, na początku warto rozróżnić kilka jej rodzajów, które w różnym stopniu pozwalają jednostce lub grupie funkcjonować w danej kulturze czy społeczności. Do nauk społecznych wprowadził je psycholog Erik Erikson w latach pięćdziesiątych XX wieku. W swoim modelu rozwojowym tożsamości podzielił ją na osiem stadiów ${ }^{10}$, które występowały w róż-

7 „Jest to zespół doznań jakie towarzyszą człowiekowi w związku z funkcjonowaniem $\mathrm{w}$ świecie przeładowanym informacjami i ich naporem. Badania wykazują, że osoby obdarzone wysoką inteligencją, aktywne, poszukujące doznań, ekstrawertyczne, radzą sobie lepiej z informacyjnym stresem niż osoby niewykazujące takich cech"; tamże, s. 311-312.

8 Tamże, s. 311.

${ }^{9}$ K. Doktorowicz (red.), Tożsamość w wieku informacji, s. 26.

${ }^{10}$ E.H. Erikson, Tożsamość a cykl życia, przekł. M. Żywicki, Poznań 2004. 
nych momentach życia ${ }^{11}$. Na koncepcji tej opierali się także inni autorzy, tworząc swoje propozycje. Ograniczając się jedynie do dwóch, można wspomnieć o narracyjnej koncepcji historii życia ${ }^{12}$ Dan McAdams ${ }^{13}$. W koncepcji tej człowiek tworzy zintegrowaną opowieść, w której łączy różne aspekty i elementy swojej biografii. Zakłada ona zmieniający się podmiot $\mathrm{w}$ zmieniających się sytuacjach. Ważna jest cała historia - tożsamość narracyjna. Inne podejście stanowi koncepcja osiągania tożsamości Jamesa Marica ${ }^{14}$. Twierdzi on, że każda osoba może mieć jedną z czterech typów tożsamości ${ }^{15}$. A jaką dany człowiek będzie mieć, decydują dwa główne czynniki, to jest eksploracja oraz podejmowanie zobowiązań. Eksploracja to moment poszukiwania społecznych oraz własnych granic fizycznych i psychicznych, osobistych upodoban, możliwości. Podejmowanie zobowiązań polega natomiast na wybraniu konkretnej drogi, opcji i podążaniu nią, i nie musi poprzedzać go eksploracja.

Tożsamość można dzielić i rozumieć na wiele różnych sposobów. Możemy mówić o tożsamości osobistej, grupowej, społecznej, kulturowej i rozumieć ją w sposób logiczny (jako coś identycznego) lub jako poczucie tożsamości - „oznacza pewną subiektywną prawdę o sobie samym, z akcentem na wewnętrzną autentyczność - «bycie sobą» - jako zaprzeczenie maski, konwencji lub roli"16. Jak łatwo się domyśleć, w zależności o której tożsamości dokładnie mowa i w jakim ujęciu, znaczenie mogą mieć różne czynniki, które tę tożsamość budują lub zmieniają. Również proces tworzenia każdej z nich wygląda nieco inaczej. $W$ tym tekście mowa w znacznej mierze o tożsamości osobistej w kontekście nowych czynników, jakie daje Internet, czy mówiąc szerzej nowe technologie. Tożsamość osobista ma w sposób naturalny zbiory elementów wspólnych również z innymi ujęciami. Prawidłowo ustrukturyzowana tożsamość osobista pozwala człowiekowi na prawidłowe funkcjonowanie:

Do refleksyjnego opracowania tożsamości dochodzi w okresie dorastania. W progu tego okresu rozwija się myślenie formalno-operacyjne, pozwalające uczynić z siebie i posiadanych właściwości przedmiot poznania oraz umożliwiające tworzenie koncepcji siebie na poziomie pojęć abstrakcyjnych (...) Zadaje sobie pytania (młody człowiek), w jakim stopniu został ukształtowany, a w jakim może kształtować sam siebie.

${ }^{11}$ Cztery przynależały do okresu niemowlęctwa i dzieciństwa, piąta do okresu dojrzewania, a kolejne trzy dotyczyły wieku dojrzałego, włączając w to również starość.

${ }^{12}$ K. Jezierski, Zagadnienie tożsamości w ujęciu Dana P. McAdamsa i Ericka H. Eriksona, Psychologia Rozwojowa, 2010, 15(4), s. 93.

${ }^{13}$ D.P McAdams, The stories We Live By: Personal Myths and the Making of the Self, New York 1993.

${ }^{14}$ J.E. Marcia, Identity in adolescence, [w:] Handbook of adolescent psychology, red. J. Adelson, New York 1980.

${ }^{15}$ Tożsamość dojrzała, moratoryjna, lustrzana oraz rozproszona.

${ }^{16}$ P.K. Oleś, O różnych rodzajach tożsamości oraz ich statości i zmianie, [w:] Tożsamość i jej przemiany a kultura, red. P.K. Oleś, A. Batory, Lublin 2008, s. 42. 
Czasem odrzuca to kim jest, w imię tego, kim może się stać. Definiuje siebie, określa swój stosunek do wartości, planuje przyszłość ${ }^{17}$.

Dla młodego człowieka ważne są w tym czasie pytania typu: kim jestem? dokąd zmierzam? co jest dla mnie ważne ${ }^{18}$ oraz podważanie wielu zastanych norm poprzez stawianie pytania „dlaczego?". Również po ukonstytuowaniu się tożsamości możliwa jest jej zmiana, ponieważ jest to raczej nieustanny proces, aniżeli konkretny stan, będący efektem tego procesu ${ }^{19}$. Z. Bauman w swoim tekście Ponowoczesne wzory osobowe $e^{20}$ twierdzi, iż pytanie o tożsamość jest zasadne tylko dlatego, że człowiek znajduje się w miejscu, gdzie nie ma pewności, a analiza tożsamości może nastąpić, kiedy mamy do wyboru więcej niż dwie opcje. Dzieje się tak, ponieważ na obraz nas samych duży wpływ mają doświadczenia, jakie nabywamy przez całe życie. Również momenty krytyczne mogą w sposób definitywny zmienić obraz nas samych. Istotne znaczenie $w$ budowaniu i poczuciu tożsamości mają także procesy nieświadome. To, jak chodzimy, mówimy, czy jesteśmy wrażliwi - wszystko również wpływa na to, jak siebie widzimy, jak doświadczamy świat zewnętrzny i jak przetwarzamy różne bodźce zewnętrzne. Oprócz doświadczania bezpośredniego, również refleksja nad tym co nas spotkało ma wpływ ${ }^{21}$.

To, co jest nowe we współczesnym świecie, to nie sama zmienność, bo ona zawsze towarzyszyła człowiekowi, przynajmniej w pewnym stopniu. Novum $\mathrm{w}$ tej tematyce stanowi natężenie tej zmienności oraz wręcz oczekiwanie, wymuszanie jej. Istnieje moda na próbowanie wszystkiego, szukanie swoich granic, odwlekanie decyzji na temat własnej przyszłości. Obrazem tego może być jedna $\mathrm{z}$ akcji reklamowych magazynu LOGO22: Wybierz swoja drogę, ale najpierw spróbuj wszystkiego - brzmi jej slogan. Odnosi się to do wyidealizowanego archetypu nowoczesnego mężczyzny, który oprócz dobrej pracy powinien mieć czas na siłownię, wyjazdy, gotowanie, staranny ubiór oraz znajomość wszystkich nowinek ze świata motoryzacji, elektroniki, mody i sportu. Dopełnieniem całości jest postać mężczyzny, która widnieje na plakatach obok wspomnianego hasła reklamowego - męska, naznaczona ostatnimi przygodami twarz zdradza, że osoba ta lubi ekstremalne przygody, ubiór natomiast sugeruje, że jest on człowiekiem z klasą, zaś cała postura świadczy, że mamy do czynienia z człowiekiem renesansu. Popkultura ma znaczący wpływ na młodego człowieka, a więc na budowanie jego tożsamości. Nie można jej pomijać w rozważaniach

17 Tamże, s. 45.

18 Tamże.

${ }^{19}$ K. Waszczyńska, Wokót problematyki tożsamości, Rocznik Towarzystwa Naukowego Płockiego, 2014, 6, s. 52.

${ }^{20}$ Z. Bauman, Ponowoczesne wzory osobowe, Studia Socjologiczne, 2011, 1(200), s. 436.

${ }^{21}$ P.K. Oleś, O różnych rodzajach tożsamości, s. 49.

${ }^{22}$ Magazyn przeznczony dla mężczyzn. Porusza tematy mody, gadżetów, jedzenia, męskich hobby itp. 
na ten temat, ponieważ towarzyszy mu ona w kształtowaniu postawy względem ciała, ubioru, orientacji seksualnej (akceptacji lub odrzucenia odmienności), gustu estetycznego, zwyczajów konsumenckich, czy - co jest najbardziej brane pod uwage w tym artykule - aktywności podejmowanych w wirtualnym świecie ${ }^{23}$. Aktywności te pozwoliły na stworzenie nowych środowisk, w których przebywa młody człowiek. Tworzą się nowe relacje między cielesnością, tożsamością a społecznością. Powstają alternatywne wspólnoty wirtualne, których przewagą jest odmiejscowienie i odczasowienie. Ich podstawą są jedynie jednostki wchodzące we wzajemne interakcje ${ }^{24}$, często bez udziału fizyczności realnej, a jedynie wirtualnej prezentacji (avatar).

Na zakończenie tego wątku przybliżmy refleksję, jaką dzieli się Bauman pod koniec swojej książki Ponowoczesność jako źródło cierpień. Kiedy pożegnaliśmy narzucane nam autorytety i wywalczyliśmy wolność do samodzielnego decydowania i możliwości podejmowania prób osiągnięcia różnych celów, wielu z nas, niestety, nie pamięta, lub nie chce pamiętać, że wraz z wolnością otrzymaliśmy odpowiedzialność za swoje działanie oraz niepewność, czy owo działanie przyniesie oczekiwany skutek. I jak wolność oznacza odpowiedzialność, tak absolutna wolność oznacza absolutną odpowiedzialność. Nic dziwnego, że wiele osób młodych wierzy w wizję świata wolnego, pełnego możliwości, który zachęca do wypróbowania jak największej ilości rzeczy. Mało kto stara się pamiętać, że za swoje wybory przyjdzie znacznej większości ludzi ponieść konsekwencje:

Nie ulega wątpliwości, że szlak życiowy człowieka wolnego nie jest usłany różami. Udręki i katusze człowieka skazanego na wolny wybór, które krytycy życia nie ugruntowanego w tożsamościach przypisanych starają się zawrzeć w pojęciu „płytkiej” czy „pozbawionej głębszego znaczenia" tożsamości, nie są wydumane. Męki są wielorakie i na różne sposoby odczuwane, ale wszystkie one sprowadzają się do uporczywego, a męczącego poczucia niepewności, co przyszłość przyniesie i co człowieka czeka ${ }^{25}$.

Doszliśmy do momentu, gdzie efekty rozwoju technologii, konsumpcjonizmu, globalizacji są widoczne gołym okiem. Nasze dotychczasowe działania doprowadziły nas do ery antropocenu, gdzie koszt naszego dotychczasowego dobrobytu cały czas był przenoszony w przyszłośćc ${ }^{26}$. Nadchodzą czasy, kiedy będziemy musieli zmierzyć się z nawarstwiającymi się problemami

23 A. Ostaszewska, Popkulturowe ramy tożsamości. Media, kultura popularna, internet jako nowe środowiska kształtowania tożsamości, Ośrodek Rozwoju Edukacji 2012, s. 6, http://www.bc.ore. edu.pl/Content/666/popkulturowe+ramy+tosamoci.pdf, [dostęp: 04.04.2020].

${ }^{24}$ G. Osika, Technologie medialne - czynnik ujednolicający czy różnicujący projekty tożsamościowe jednostek, [w:] Via Communicandi. Prace z Antropologii Komunikacji i Epistemologii Społecznej, red. B. Sierocka, Wrocław 2012, s. 110.

25 Z. Bauman, Ponowoczesność, s. 366.

26 E. Bińczyk, Epoka człowieka. Retoryka i marazm antropocenu, Warszawa 2018, e-book paragraf 11.19 . 
i ponownie zacząć ponosić odpowiedzialność za siebie i swoje zachowania. Nierozłącznie wiąże się to $\mathrm{z}$ tożsamością człowieka i jego gotowością na to, aby uznać siebie za aktywny podmiot, którego odpowiedzialne zachowanie ma znaczenie i wpływ na otaczający go świat.

\section{Rola szkoły}

Według niektórych raportów o stanach oświaty, zarówno globalnej jak i w poszczególnych krajach, ciągle przeważa w szkołach nauczanie nad uczeniem się. To w sposób konieczny prowadzi do fałszywego intelektualizmu szkolnego, objawiającego się znaczącym zakresem zdobytych przez uczniów informacji przy minimalnym zasobie kompetencji w zakresie samodzielnego uczenia się. Jednym $z$ bardziej znanych dokumentów we wskazanym wyżej przedmiocie jest Raport Banku Światowego z $2018^{27}$ Learning to realize education's promise. Jego twórcy zrównują kryzys (nieefektywnej) edukacji z kryzysem moralnym. Podkreślają, iż edukacja bez uczenia się to marnowanie szans ${ }^{28}$ i pokazują, że drogą do polepszenia systemów edukacji jest koncentracja na wzmocnieniu wagi samej edukacji, zmniejszania różnic i likwidowania wykluczeń w edukacji, podążania za nowymi metodami nauki i innowacjami, których celem jest polepszenie zdobywanego wykształcenia. Również w Polsce powstały opracowania o podobnej tematyce, jak na przykład Raport ze szkół polskich z 2017 roku' ${ }^{29}$ o innowacyjności w szkołach polskich. W wyzwaniach, jakie stoją przed szkołą, nauczycielem, czy też szerzej edukacją (na każdym poziomie! zarówno edukacji sformalizowanej, jak i niesformalizowanej) jest efektywne wspomaganie ucznia/studenta/klienta. Zadanie to polega na pomocy jednostce - nie tylko posiąść określony zasób informacji, pozwalający wykształcić indywidualną wiedzę (poprzez pobudzanie sprawczości ucznia jako architekta osobistej wiedzy!), ale przede wszystkim nabyć umiejętności funkcjonowania $\mathrm{w}$ zmiennym świecie. Warto, by odbierać (faktycznie) ten świat jako świat możliwości, różnego rodzaju bogactwa, coś pozytywnego, nie zaś jako świat niebezpieczeństwa, niepewności, zagubienia. Jest to zadanie niebagatelne i z pewnością nie ma prostej recepty, jak można dojść do tego celu. Ewentualne propozycje edukacyjne muszą się zmierzyć z wieloma wyzwaniami: wspomnianym zalewem informacyjnym, wszechobecną technologią, indywidualnymi preferencjami uczniów i tym podobnymi. Obecny system był stworzony na potrzeby rewolucji przemysłowej i odpowiadał zapotrzebowaniu,

27 World Bank Group, Learning to realize education's promise, Washington DC 2018, źródło internetowe: https:/ / www.worldbank.org/en/publication/wdr2018\#, [dostęp: 08.06.2020].

28 Schooling without learning is a wasted opportunity, s. 3.

29 Szkoła dla innowatora, Jan Fazlagić (kierownik projektu), Kalisz 2018. 
które stawiał przed nią świat industrialny. Człowiek pełnił ówcześnie rolę, jaką od parudziesięciu dekad zabierają mu maszyny. Czasy te wymagały od niego powtarzalności wykonywania wcześniej ustalonych czynności. Wykształcenie zdobywane $\mathrm{w}$ tych czasach nie miało cech innowacyjności, indywidualności i tym podobnie. Współcześnie idziemy w kierunku, kiedy to sam człowiek nadaje sobie wartość i sens życia, pracę dla samego siebie, nie w celach zarobkowych.

Z pewnością można wymienić kilka najważniejszych wyzwań stojących przed szkołą obecnie.

Przede wszystkim jednak dla badaczy i edukatorów obecność młodzieży w sieci jest wielkim wyzwaniem, polegającym głównie na konieczności określania zmian, jakie są powodowane w pokoleniu cyfrowym z jednej strony, a z drugiej - jak wykorzystać tę niemal naturalną obecność wszystkich uczniów w sieci do ich aktywizacji w przestrzeni edukacji formalnej ${ }^{30}$.

Zatem, jaki stosunek powinna mieć szkoła do technologii, jak i kiedy powinna ją wykorzystywać w życiu szkolnym każdego ucznia. Zadania jej nie mogą się ograniczać jedynie do mówienia (aspektu teoretycznego) o tym, jak powinno się wykorzystywać technologię i jak zdobywać dzięki niej odpowiednie informacje, ale również demonstracji przykładów (aspektu praktycznego) i kształtowania u ucznia zdrowych nawyków (higieny pracy) w codziennym użytkowaniu swoich prywatnych urządzeń. Innym wyzwaniem jest wspomniany wyżej zalew informacyjny. To właśnie weryfikacja informacji stawia potencjalnie najtrudniejsze zadanie przed człowiekiem przebywającym w świecie wirtualnym, który pobiera codziennie z niego różne informacje (chodzi tutaj w szczególności o te natury opinioi wiedzotwórczej). Kreowanie krytycznych postaw względem czytanej informacji w Internecie na różnych forach, portalach społecznościowych i tym podobnych jest obecnie fundamentalne dla wykształcenia człowieka. Wiadomo już, że dzięki odpowiedniemu algorytmowi można (chociaż nadal w niewielkim stopniu) wpłynąć na wybory konsumenckie oraz przy posiadaniu odpowiedniej ilości informacji wyjściowych przewidzieć preferencje każdego konsumenta. To jednak nie jest koniec; właściwe manipulowanie pozycjonowaniem odpowiednio naładowanych emocjonalnie tekstów może wpłynąć nawet na oddanie głosu na konkretnego kandydata w wyborach (jak miało to miejsce $\mathrm{w}$ kampanii wyborczej na prezydenta USA w 2016 $\left.\mathrm{roku}^{31}\right)$. Nie tylko manipulowanie informacją $\mathrm{w}$ sposób tendencyjny czy też wielość dostępnych informacji jest problemem. Na pierwsze miejsce, w pro-

${ }^{30}$ S. Dylak, Architektura wiedzy w szkole, Warszawa 2013, s. 67.

${ }^{31}$ H. Fry, Hello world. Jak być człowiekiem w epoce maszyn, przekł. S. Musielak, Kraków 2019, s. 60 . 
blematyce weryfikacji informacji, wyłania się zjawisko istnienia coraz doskonalszych fake newsów, które coraz częściej odgrywają ważną rolę w mediach społecznościowych. Pewną ich odmianą audiowizualną jest deepfake ${ }^{32}$, chociaż technologia ta może zapewnić aktorom nieśmiertelność i możliwość grania $w$ filmach nawet po śmierci (w dowolnym wariancie wiekowym), to może również służyć do tworzenia nieprawdziwych wypowiedzi ważnych ludzi sztuki, biznesu, czy polityki. Jak może wyglądać taka wypowiedź pokazał w serwisie YouTube amerykański komik Jordan Peele, który w nieco humorystyczny sposób przedstawił nieprawdziwą wypowiedź byłego prezydenta USA Baracka Obamy ${ }^{33}$.

Najbardziej efektywna praktyka, jaka może nauczyć każdego człowieka odpowiedniej postawy do zastanej informacji, powinna być na poziomie uczeń - nauczyciel. Jeżeli chcemy, by szkoła kształciła człowieka, to musimy oczekiwać, że nauczy również sposobów na radzenie sobie z trudnościami, jakie mogą w późniejszym czasie ich spotkać. Inaczej mówiąc, niezwykle trudno może być jednostce samodzielnie zacząć krytycznie patrzeć na informacje. Powodem tego jest duża łatwość w znajdowaniu wielu źródeł o podobnej treści (przekonywanie przekonanych) i tendencja człowieka do pozostawania w swojej już wykreowanej strefie komfortu. Krytyczne myślenie wymaga od jednostki przynajmniej tego, by była w stanie wyobrazić sobie możliwość, że jej przekonania już ukształtowane wcześniej mogą być fałszywe (co nie oznacza, że w momencie ich kształtowania były one takie). Ten wcale niełatwy krok jest jedynie przyczynkiem do faktycznego, głębokiego myślenia krytycznego.

Pojawia się coraz więcej badań, ukazujących, iż funkcjonowanie dziecka w świecie cyfrowym nie musi powodować negatywnych skutków ${ }^{34}$. Oczywiste jest również to, że znaczenie ma wiek użytkownika, jego płeć i tym podobne. Mamy do czynienia tutaj z dwukierunkowością, co znaczy, że istnieje również odwrotna korelacja, to jest niewłaściwe i szkodliwe używanie portali społecznościowych, czy szerzej - technologii, jest symptomem dysfunkcjonalności danej jednostki w życiu codziennym. Czy to znaczy, że nie powinniśmy trzymać ręki na pulsie i nie zwracać uwagi na potencjalne niebezpieczeństwa, kiedy mowa o nowościach w dziedzinie technologii informatycznej? Oczywiście, że nie.

${ }^{32}$ Technika obróbki obrazu i dźwięku pozwalająca na manipulowanie wypowiedziami lub tworzenie zupełnie nowych przy zachowaniu poprawności ruszania ustami i gestykulacji.

${ }^{33}$ J. Peele, You Won't Believe What Obama Says In This Video!, www.youtube.com/ watch?v=cQ54GDm1eL0 [dostęp: 20.12.19].

${ }^{34}$ L. Denworth, The Kids Are All Right, Scientific American, 2019, 321(5), s. 45-49. 


\section{Efekty przebywania młodzieży w środowisku cyfrowym}

Mówiąc o młodzieży i jej umiejętnościach związanych z korzystaniem z technologii, warto zastanowić się, czy nie weszliśmy przez przypadek w ślepy zaułek, spowodowany tym, że jako obserwatorzy młodzieży przeceniliśmy jej możliwości. Bez wątpienia jest to, że współczesne dzieci i młodzież znacznie więcej czasu spędzają w Internecie, jednak w wielu wypadkach spędzają go na "tradycyjnych" aktywnościach, z tą różnicą, że zamiast kilku nośników (telewizor, radio, książka) mają jeden. I to już przeważnie nie tradycyjny komputer stacjonarny ani nawet laptop, a swój osobisty smartfon. Jedynie 1 osoba na $10 \mathrm{w}$ badaniach EU Kids Online nie deklarowała posiadania własnego smartfonu. W swoim wystąpieniu Pyżalski zauważył35, że bycie online jest $\mathrm{w}$ dzisiejszych czasach zupełnie czymś innym niż kiedyś, z zaznaczeniem, że to kiedyś było 10/15 lat temu, czyli w 2005/2010 roku. Jesteśmy online liczbowo znacznie więcej niż kiedyś. Na znaczeniu traci pytanie dotyczące dziennego czasu spędzonego online. Jest ono nieprecyzyjne i wiele osób mogłoby z pewnością napisać $24 \mathrm{~h}$ - wystarczy, że nie wyłączą transmisji danych w swoich telefonach lub są zawsze połączeni z jakąś siecią WiFi. Pojęcie „bycie online" zmieniło absolutnie swoje znaczenie i stało się znacznie mniej konkretne, a bardziej rozmazane i mgliste. Natomiast, jak wcześniej zostało wspomniane, czynności, jakich podejmują się młodzi ludzie, są czynnościami w dużej mierze prostymi, nieangażującymi. Oznacza to, że nie nastąpił żaden znaczący postęp jakościowy. Smutną prawdą jest to, że duży odsetek młodych ludzi przebywając $\mathrm{w}$ świecie wirtualnym, nie robi nic twórczego, krytycznego, rozwijającego. Sami tego nie ukrywają i dość otwarcie mówią o brakach, jakie mają w kompetencjach cyfrowych, a głównie dotyczących wyszukiwania i weryfikacji napotkanych informacji ${ }^{36}$. Tak więc, pomimo że są w stanie znaleźć informacje, które teoretycznie mogą się im przydać i które mogą wykorzystać do nauki na sprawdzian czy odrobienia lekcji, jednak znalezionych informacji nie są w stanie poprawnie zweryfikować. Może to być spowodowane tym, że istnieje dużo różnych portali dla uczniów oferujących gotowe odpowiedzi na wiele standardowych pytań. Nie ma tam przeważnie podanych źródeł, autora, ani linków dla zainteresowanych tą tematyką, aby móc poczytać, dowiedzieć się więcej. Posiadają oni (młodzież) natomiast łatwość obsługi nowych urządzeń, która jest dla nich w dużej mierze intuicyjna.

Przyczyny braku postępu jakościowego w umiejętnościach młodych ludzi w użytkowaniu komputera i przebywaniu w Internecie można szukać

${ }^{35}$ J. Pyżalski, Co ważnego mówią nam najnowsze badania EU Kids Online?, https://www. youtube.com/watch?v=jl_pX5RTBRQ, [dostęp: 10.01.20].

${ }^{36}$ J. Pyżalski i in., Polskie badanie EU Kids Online 2018, Poznań 2019, s 29. 
w kilku miejscach (rodzina, szkoła, brak odpowiednich narzędzi). Istnieje korelacja między korzystaniem $\mathrm{z}$ technologii (komputera) a polepszeniem się wyników uczenia. Wniosek, jaki można z tego wyciągnąć może być następujący: należy inwestować w nowe technologie, ponieważ są one preferowane przez uczniów, ich wykorzystanie w nauce spowoduje zwiększoną atrakcyjność, wyjście naprzeciw potrzebom i oczekiwaniom ucznia. Efektem końcowym tego będą lepsze wyniki w nauce w szkołach lepiej wyposażonych i z lepszym dostępem do sprzętów posiadających dojście do Interne$\mathrm{tu}^{37}$. Odpowiedź na to nie jest jednak tak jednoznacznie prosta. Jak wskazuje Raport $\mathrm{OECD}^{38} \mathrm{z} 2015$ roku Students, Computers and Learning. Making the connection ${ }^{39}$, zajmujący się analizą nabywania umiejętności cyfrowych a środowisk w jakich uczą się studenci:

Może istnieć kilka wyjaśnień dotyczących obserwowania silnych związków między wynikami uczniów a korzystaniem z komputerów. Relacje te mogą odzwierciedlać związek przyczynowo-skutkowy między dostępem/użytkowaniem komputera a wydajnością; ale mogą również odzwierciedlać odwrotną zależność, w wyniku której (oczekiwana) zwiększanie wydajności napędza inwestycje w komputery. Na przykład kraje, szkoły i rodziny, które są mniej zadowolone z wyników swoich uczniów, mogą zainwestować więcej w nowe narzędzia lub chętniej je wypróbować, mając nadzieję na poprawę tych wyników. Nawet przy braku związków przyczynowych relacje te mogą odzwierciedlać powiązania dostępu i korzystania z komputera z innymi zmiennymi, takimi jak dostępne zasoby, trudność w przyciągnięciu dobrych nauczycieli itp., które same są związane z wydajnością ${ }^{40}$.

Ten sam raport wskazuje, że nie zawsze więcej znaczy lepiej. Jak twierdzą autorzy tego raportu:

Ogólnie związek między korzystaniem z komputera w szkole a wydajnością ma charakter graficzny zilustrowany kształtem wzgórza, co sugeruje, że ograniczone korzystanie z komputerów w szkole może być lepsze niż w ogóle nieużywanie, ale poziomy wykorzystania komputera przekraczające obecną średnią OECD są związane ze znacznie gorszymi wynikami ${ }^{41}$.

Informacje te wskazują jasno, że nie możemy w prosty sposób łączyć ze sobą wyników uczniów z możliwością korzystania z komputera. Należy pamiętać zatem, że jedynie odpowiednie stymulowanie pracy ucznia w Interne-

${ }^{37}$ Jest to dość powszechne twierdzenie, które ma znamiona zdroworozsądkowego wnioskowania.

${ }^{38}$ Organisation for Economic Co-operation and Development/ Organizacja Współpracy Gospodarczej i Rozwoju.

39 Students, Computers and Learning: Making the Connection (2015), PISA, OECD Publishing. http://dx.doi.org/10.1787/9789264239555-en, [dostęp: 06.04.2020]

40 Tamże, s. 147.

${ }^{41}$ Tamże, s. 146. 
cie będzie przynosiło oczekiwane rezultaty (związek przyczynowo-skutkowy). Obecność w Internecie może być równie niewydajna, jak ogólny brak dostępu do Internetu. Wskazówek, jak osiągnąć pozytywne efekty kształcenia może dostarczyć pochylenie się nad uwagą Pyżalskiego, aby w dobie posiadaczy smartfonów zastanowić się, o ile powinniśmy nadal inwestować w urządzenia (co pokrywa się z opinią OECD), a na ile w dobrą kadrę ${ }^{42}$. Chociaż jedno i drugie jest niezwykle ważne, to wydaje się, że uwagę tę można sprowadzić do jednego twierdzenia. Nie można zapomnieć ani rozwijać jedynie jednej z tych dwóch rzeczy. Odpowiednio przygotowany nauczyciel, wspierany przez właściwe rozwiązania technologiczne, będzie $\mathrm{w}$ stanie pokazać młodzieży, jak poprawnie poruszać się po świecie cyfrowym w ich własnych smartfonach, jak dbać o swoją prywatność i bezpieczeństwo w Sieci.

Wraz ze zmieniającą się technologią zmieniają się preferencje użytkowników. A jak się one zmieniły, pokazuje wspomniany wyżej Raport EU Kids Online, który wskazuje, jak mało aktualne ${ }^{43}$ są materiały dotyczące tej tematyki po niecałych 10 latach... W 2010 roku:

Jedynie 13\% używało laptopa własnego i 13\% laptopa wspólnego z innymi użytkownikami. Telefon komórkowy do łączenia z Internetem używany był przez $37 \%$ młodych ludzi. Wyraźnie więc widać dominację stacjonarnego korzystania z Internetu ${ }^{44}$,

natomiast w 2019 roku relacja ta wyglądała następująco:

Zdecydowanie na pierwszym miejscu wśród urządzeń służących do łączenia się z Internetem znajduje się telefon komórkowy/smartfon. Korzystało z niego codziennie lub częściej 82,5\% badanych. Odsetek badanych korzystających do łączenia się z Internetem za pomocą telewizora wynosił prawie $57 \%$, a za pomocą laptopa i komputera stacjonarnego prawie $40 \%{ }^{45}$.

Tak duża dynamika pokazuje, iż szkoła powinna w znacznie szybszy i bardziej przemyślany sposób zmieniać się, by nadążyć za uczniami. Jeżeli tyle się zmieniło w ciągu jednej dekady, a wiele wskazuje na to, że zmiany cały czas przyspieszają, to niewykluczone, że za kolejne dziesięć lat preferencje uczniów będą absolutnie inne. Być może powszechnie dostępne staną się już specjalne soczewki z chipem na oko lub wszczepienie fizyczne chipów do mózgu, a może idea Google Glass wróci do łask. Odnośnie tej tematyki może-

${ }^{42}$ J. Pyżalski, Co ważnego mówią nam najnowsze badania.

${ }_{43}$ Nie jest to równoznaczne, oczywiście, z nieprzydatnością takich informacji. Wręcz przeciwnie, pokazują one, jak dużą dynamikę ma w chwili obecnej świat cyfrowy i jak szybko się rozwija technologia. Należy natomiast z krytycznym nastawieniem podchodzić do wniosków takich badań, raportów, przemyśleń.

${ }^{44}$ J. Pyżalski i in., Polskie badanie, s. 17.

${ }^{45}$ Tamże, s. 20. 
my w dużej mierze jedynie zgadywać... Kończąc ten wątek, warto pamiętać, że efekt przebywania młodzieży $w$ środowisku medialnym/cyfrowym nie ma charakteru zero-jedynkowego. Jest to wpływ wielowektorowy i nad tym konieczne są nowe badania, nie zaś nad tym, jak bardzo ludzie uzależniają się od Internetu, czy jakie niegodziwości sprawiają innym w czasie przebywania $\mathrm{w}$ Internecie. Jest to skutkiem tego, że szkoła nie potrafi zaoferować młodzieży niczego sensownego, by ich obecność w Internecie była bardziej kreatywna, pozytywna - oni i tak tam będą... Najbardziej prawdopodobnym skutecznym rozwiązaniem może być zmiana aktywności zadaniowej, przy pozostawaniu w tym samym bądź zbliżonym środowisku (warunkach) ${ }^{46}$.

\section{Podsumowanie}

Świat jest tkanina, która przędziemy codziennie na wielkich krosnach informacji, dyskusji, filmów, ksiażek, plotek, anegdot. Dziś zasięg pracy tych krosien jest ogromny - za sprawa Internetu prawie każdy może brać udziat w tym procesie, odpowiedzialnie i nieodpowiedzialnie, z miłościa i nienawiścia, ku dobru i ku złu, dla życia i dla śmierci. Kiedy zmienia się ta opowieść - zmienia się świat ${ }^{47}$.

Słowa te wypowiedziała $\mathrm{w}$ wystąpieniu noblowskim Olga Tokarczuk. Przemówienie to jest warte uwagi szczególnie w świecie nauk społecznych i humanistycznych. Pisarka w wielu miejscach, w sposób niezwykle ciekawy diagnozuje problemy współczesnego świata. Wskazuje, iż nie mamy przygotowanej narracji, odpowiedniej do współczesnego świata, która mogłaby go tłumaczyć. Na siłę pozostając przy starych narracjach, które nie są w stanie prawidłowo opisywać tego świata. W tym wszystkim pozycja młodego człowieka nie kreśli się najlepiej. Problem tożsamości w kontekście przestrzeni cyfrowej jest wielopoziomowy. Nie można go w żadnym wypadku oddzielić od szerszego kontekstu kulturowego, ponowoczesnej zmienności, potrzeby edukacji, walki z zalewem informacyjnym. Zaistniała potrzeba zrewidowania naszych przyzwyczajeń, które często zostały nam narzucone przez prywatne korporacje. Współczesny człowiek nie szuka informacji, on je googluje ${ }^{48}$, a to co wygoogluje uważa za prawdę. Nie bez kozery po przestrzeni cyfrowej wędruje żart: gdzie najlepiej schować zwłoki? Na drugiej stronie w Google. Młody człowiek ma wiele zasobów, których nie zdążył rozwinąć przez tak krótki

${ }^{46}$ K. Konarzewski, Podstawy teorii oddziatywań wychowawczych, Warszawa 1982.

47 O. Tokarczuk, Przemowa noblowska Olgi Tokarczuk, Svenska Akademien, Sztokholm 2019, s. 3, https://www.nobelprize.org/uploads/2019/12/tokarczuk-lecture-polish.pdf, [dostęp: 10.05.2020].

${ }^{48}$ Y.N. Harari, 21 lekcji na XXI wiek, przekł. M. Romanek, Kraków 2018, s. 82. 
okres swojego życia. Do efektywnego poruszania się po przestrzeni cyfrowej nie wystarczy mieć umiejętności „fizyczne” i wiedzę praktyczną. Nadal wymagana jest Wiedza, która z pewnością jest znacznie bardziej wykształcona i ugruntowana u człowieka dorosłego,

...szalona prędkość rozlewania się zaangażowania nastolatków w przestrzeń cyfrową nie idzie $w$ parze $z$ opanowywaniem moralnych i społecznych reguł korzystania $z$ tej przestrzeni ${ }^{49}$.

Tak więc, wiedza potrzebna dzieciom, młodzieży dotyczy aspektów życia społecznego, powszechnie przyjętych reguł, co wypada a co nie. Właśnie te zdolności, pomimo że nie są kojarzone ze światem cyfrowym, są bardzo ważne dla poprawnego funkcjonowania $\mathrm{w}$ nim $^{50}$.

Nie istnieje żaden złoty środek ani magiczne zaklęcie, które spowoduje, że za rok, dwa wyeliminuje się problemy omawiane powyżej. Zapewne nigdy nie nastąpi taki moment, kiedy ludzkość będzie mogła sobie powiedzieć, że zakończyła etap wszelkiego problemu $\mathrm{z}$ technologią. $\mathrm{W}$ tym wszystkim ważne są nasze codzienne, indywidualne decyzje i wybory, czy przeczytać fragment książki, czy obejrzeć wspólnie z bliskimi film, czy porozmawiać z dzieckiem o jego dniu, czy zaproponować wspólny wieczór gier. Każdy z nas przyczynia się do ogólnego obrazu społeczeństwa i jak każdy może widzieć konkretne problemy w różny sposób, tak też istnieje wiele dróg, by harmonijnie wzrastać w świecie zmienności. Max Tegmark zakończył swoją książkę słowami, którymi autorzy chcieliby również zakończyć powyższy artykuł:

Jesteśmy strażnikami przyszłości życia, teraz kiedy tworzymy erę sztucznej inteligencji. (...) Teraz czuję, że nie ma niczego nieuniknionego w przyszłości i wiem, że jest znacznie łatwiej coś zmienić niż kiedyś myślałem. Nasza przyszłość nie jest wypisana w kamieniu i tylko czeka, by się urzeczywistnić - to my ją stworzymy. Więc stwórzmy razem inspirującą przyszłość! ${ }^{51}$

\section{BIBLIOGRAFIA}

Bauman Z., Ponowoczesne wzory osobowe, Studia Socjologiczne, 2011, 1(200).

Bauman Z., Ponowoczesność jako źródło cierpień, Wydawnictwo Sic!, Warszawa 2013.

Bińczyk E., Epoka człowieka. Retoryka i marazm antropocenu, Wydawnictwo Naukowe PWN, Warszawa 2018.

${ }^{49}$ S. Dylak, Architektura wiedzy, s. 67.

50 A. Zdrodowska, Wyniki badania EU Kids Online 2018 w Polsce, https://www.youtube. com/watch? v=7bz7UfJ1Hu0, [dostęp: 10.01.2020].

${ }_{51}$ M. Tegmark, Life 3.0 - Being Human in the Age of Artificial Intelligence, Allen Lane, 2017, s. 335 . 
Denworth L., The Kids Are All Right, Scientific American, 2019, 321(5).

Doktorowicz K. (red.), Tożsamość w wieku informacji. Media. Internet. Kino, Wydawnictwo Uniwersytetu Śląskiego, Katowice 2015.

Dylak S., Architektura wiedzy w szkole, Wydawnictwo Difin, Warszawa 2013.

Encyklopedia pedagogiczna XXI wieku, tom II, red. T. Pilch, Wydawnictwo Akademickie Żak, Warszawa 2003.

Erikson E.H., Tożsamość a cykl życia, przekł. M. Żywicki, Zysk i S-ka Wydawnictwo, Poznań 2004.

Fry H., Hello world. Jak być człowiekiem w epoce maszyn, przekł. S. Musielak, Wydawnictwo Literackie, Kraków 2019.

Harari Y.N., 21 lekcji na XXI wiek, przekł. M. Romanek, Wydawnictwo Literackie, Kraków 2018.

Jezierski K., Zagadnienie tożsamości w ujęciu Dana P. McAdamsa i Ericka H. Eriksona, Psychologia Rozwojowa, 2010, 15(4).

Konarzewski K., Podstawy teorii oddziaływań wychowawczych, Państwowe Wydawnictwo Naukowe, Warszawa 1982.

Marcia J.E., Identity in adolescence, [w:] Handbook of adolescent psychology, red. J. Adelson, Wiley, New York 1980.

McAdams D.P., The stories We Live By: Personal Myths and the Making of the Self, William Morrow \& Co, New York 1993.

Oleś P.K., O różnych rodzajach tożsamości oraz ich statości i zmianie, [w:] Tożsamość i jej przemiany a kultura, red. P.K. Oleś, A. Batory, Wydawnictwo KUL, Lublin 2008.

Osika G., Technologie medialne - czynnik ujednolicający czy różnicujący projekty tożsamościowe jednostek, [w:] Via Communicandi. Prace z Antropologii Komunikacji i Epistemologii Społecznej, red. B. Sierocka, Oficyna Wydawnicza ATUT, Wrocław 2012.

Ostaszewska A., Popkulturowe ramy tożsamości. Media, kultura popularna, internet jako nowe środowiska ksztattowania tożsamości, Ośrodek Rozwoju Edukacji 2012, s. 6, http:/ / www. bc.ore.edu.pl/Content/666/popkulturowe+ramy+tosamoci.pdf, [dostęp: 04.04.2020].

Peele J., You Won't Believe What Obama Says In This Video!, www.youtube.com/watch?v=cQ54GDm1eL0 [dostęp: 20.12.19].

Pyżalski J., Co ważnego mówia nam najnowsze badania EU Kids Online?, https:/ / www.youtube.com/watch?v=jl_pX5RTBRQ, [dostęp: 10.01.20].

Pyżalski J., Zdrodowska A., Tomczyk Ł., Abramczuk K., Polskie badanie EU Kids Online 2018, Wydawnictwo Naukowe UAM, Poznań 2019.

Students, Computers and Learning: Making the Connection, PISA, OECD Publishing, 2015, http:/ / dx.doi.org/10.1787/9789264239555-en, [dostęp: 06.04.2020].

Szkoła dla innowatora. Jan Fazlagić (kierownik projektu), Ośrodek Doskonalenia Nauczycieli, Kalisz 2018.

Tegmark M., Life 3.0 - Being Human in the Age of Artificial Intelligence, Allen Lane, 2017.

Tokarczuk O., Przemowa noblowska Olgi Tokarczuk, Svenska Akademien, Sztokholm 2019, s. 3, https://www.nobelprize.org/uploads/2019/12/tokarczuk-lecture-polish.pdf, [dostęp: 10.05.2020].

Waszczyńska K., Wokót problematyki tożsamości, Rocznik Towarzystwa Naukowego Płockiego, 2014, 6.

World Bank Group, Learning to realize education's promise, Washington DC 2018, źródło internetowe: https://www.worldbank.org/en/publication/wdr2018\#, [dostęp: 08.06.2020].

Zdrodowska A., Wyniki badania EU Kids Online 2018 w Polsce, https:/ / www.youtube.com/ watch?v=7bz7UfJ1Hu0, [dostęp: 10.01.2020]. 